\title{
Diastereoselective Synthesis of Substituted 2-Amino-1,3-propanediols from Morita-Baylis-Hillman Adducts
}

\author{
Paulo H. S. Paioti, Patrícia Rezende and Fernando Coelho* \\ Laboratório de Síntese de Produtos Naturais e Fármacos, Instituto de Química, \\ Universidade Estadual de Campinas, CP 6154, 13083-970 Campinas-SP, Brazil
}

\begin{abstract}
Descrevemos nesse artigo uma abordagem diastereosseletiva, a partir de adutos de MoritaBaylis-Hillman (MBH), para a preparação de sistemas 2-amino-1,3-propanodióis substituídos com estereoquímica relativa anti. Estas unidades estruturais têm sido utilizadas como intermediárias para a síntese de diversas substâncias de interesse farmacológico e comercial. Nessa estratégia, os anti 2-amino-1,3-propanodióis foram facilmente preparados por ozonólise de dióis alílicos obtidos de adutos de $\mathrm{MBH}$, seguido de uma aminação redutiva diastereosseletiva dos 2-oxo-1,3-propanodióis. Para demonstrar a utilidade desses aminodióis, eles foram transformados em oxazolidin-2-onas substituídas, que também foram utilizadas na determinação indireta da configuração relativa dos aminodióis.
\end{abstract}

We report herein a new diastereoselective approach to substituted 2-amino-1,3-propanediols with anti relative stereochemistry from Morita-Baylis-Hillman (MBH) adducts. These structural moieties have been used as intermediates for the synthesis of several compounds with relevant pharmacological and commercial interest. In this strategy, substituted anti 2-amino-1,3-propanediols were readily prepared via ozonolysis of allylic diols obtained from $\mathrm{MBH}$ adducts, followed by a diastereoselective reductive amination of the substituted 2-oxo-1,3-propanediols. To demonstrate the synthetic utility of these aminodiols, they were transformed into substituted oxazolidin-2-ones, which were also used in the indirect determination of the relative stereochemistry of the aminodiols.

Keywords: 2-amino-1,3-propanediol, Morita-Baylis-Hillman, reductive amination

\section{Introduction}

Substituted 2-amino-1,3-propanediols are important structural motifs present in many pharmacologically active compounds, such as antibiotics (e.g., chloramphenicol, fluoramphenicol and its analogues), ${ }^{1,2}$ glycosidase inhibitors $^{3}$ and sphingolipids ${ }^{4}$ (Figure 1).

2-Amino-1,3-propanediols also play an important role as key intermediates in the synthesis of oxazolidin-2-one, which can present not only antibacterial activity, but also increased synthetic applicability. ${ }^{5}$ Owing to this fact, there are several reports ${ }^{6}$ related to different approaches for the preparation of substituted 2-amino-1,3-propanediols.

In the last years, our group has been working on the preparation of valuable synthetic intermediates by exploring the potentiality of the Morita-Baylis-Hillman (MBH) reaction.${ }^{78}$ In this context, our group has previously described the synthesis of chloramphenicol and derivatives

*e-mail: coelho@iqm.unicamp.br as well as the preparation of substituted 2-quinolinones having syn 2-amino-1,3-propanediols in their structures, taking MBH adducts as substrates. ${ }^{9}$

The biological and commercial importance of this structural motif calls for the availability of as many as possible alternative methods to prepare these key compounds. Thus, it is described herein a diastereoselective approach to substituted anti 2-amino-1,3-propanediols starting from the MBH reaction. These anti-aminodiols have an endothelial differentiation gene (EDG) antagonism. This class of compounds competes with the EDG receptors and can be potentially used for the treatment of circulatory system diseases, such as arteriosclerosis, heat diseases and peripheral circulatory disorders. They can be also used against rheumatism, cancers, diabetes retinopathy, respiratory system diseases and twitch after subarachnoidal hemorrhage. ${ }^{10}$

Our approach is based on a diastereoselective reductive amination of the 2-oxo-1,3-propanediol derivatives (9-11), that are easily prepared from double bond ozonolysis 
Antibiotics<smiles>[R]c1ccc([C@@H](O)[C@H](N)CO)cc1</smiles>

1, $\mathrm{R}=\mathrm{NO}_{2} ; \mathrm{R}^{1}=\mathrm{COCHCl}_{2}$, chloramphenicol

2, $\mathrm{R}=\mathrm{NO}_{2}, \mathrm{R}^{1}=\mathrm{COCHCF}_{2}$, fluoramphenicol

3, $\mathrm{R}=\mathrm{SO}_{2} \mathrm{CH}_{3} ; \mathrm{R}^{1}=\mathrm{COCHCl}_{2}$, thiamphenicol
Sphingolipids

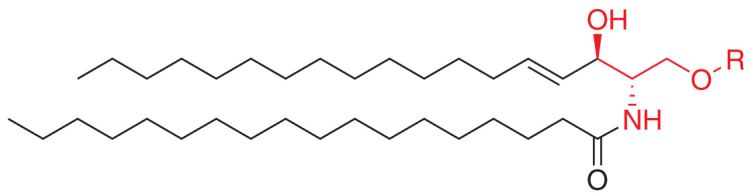

$\mathrm{R}=\mathrm{H}$, ceramide

$\mathrm{R}=$ phosphocline, sphingomyelin

$\mathrm{R}=\operatorname{sugar}(\mathrm{s})$, glycosphingolipid

Glycosidade inhibitors<smiles>OC[C@H]1NC[C@@H](O)[C@H](O)[C@@H]1O</smiles>

Deoxynojirimycin (4)

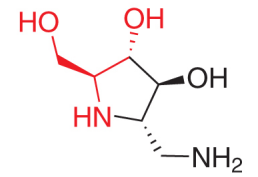

Iminocyclitol (5)

Figure 1. Biologically active compounds having 2-amino-1,3-propanediol motifs in their structures.

of an allylic diol. The latter is promptly prepared by chemoselective ester reduction of Morita-Baylis-Hillman adducts (12-14) after silylation of the secondary hydroxyl group. The retrosynthetic analysis is depicted below (Scheme 1).

The relative stereochemistry of our aminodiols is expected to be controlled during the reductive amination step of the oxo-diols (9-11). Most probably, this control could be exerted by the presence of a ligand with chelating properties in $\alpha$ position, based on the Cram-chelate model of 1,2-induction. This chelation should force the deliverance of the hydride to the less hindered face, as previously reported in other papers from our laboratory. ${ }^{11}$

In this work, it is disclosed a facile and straightforward strategy for the diastereoselective synthesis of 2-amino1,3-diols from Morita-Baylis-Hillman adducts. Additionally, it is described a regioselective total synthesis of ( \pm )-trans-isocytoxazone, an important anti-asthmatic oxazolidin-2-one. Isocytoxazone is an isomer of the natural product cytoxazone, isolated from Streptomyces sp yeasts. The biological relevance of both compounds has inspired several approaches to their racemic and asymmetric total synthesis. ${ }^{12}$ Some others 4 -substituted oxazolidinones were also synthesized using the strategy disclosed herein.

\section{Results and Discussion}

To start our work, it was prepared the $\mathrm{MBH}$ adducts (12-14, for experimental details see Supplementary Information). This was accomplished using our well-established methodology described some years ago (Scheme 2). ${ }^{13}$ In the sequence, the MBH secondary hydroxyl group was silylated to afford the protected MBH adducts (15-17) in good yields. Finally, silylated adducts 15-17 were chemoselectively reduced in the presence of DIBAL-H (diisobutylaluminium hydride) at $-72{ }^{\circ} \mathrm{C}$, to afford the allylic diols 18-20, in overall yields ranging from 67 up to $72 \%$ (Scheme 2).

Silylation was closely related to the reduction and ozonolysis steps. Previous attempts to conduct the ester reduction with the unprotected adducts have required the addition of an excess of DIBAL-H and gave the required allylic diols in low yields ( $c a .50 \%$ ). When ozonolysis is performed with silylated adducts, the yields are higher,

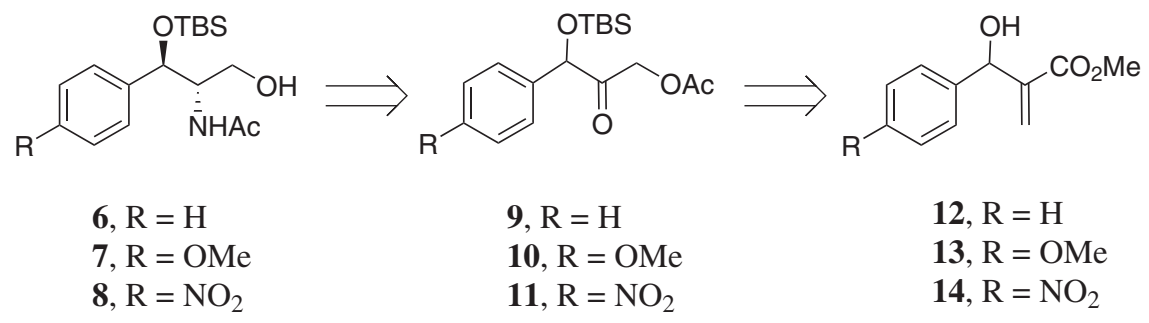

Scheme 1. Retrosynthetic analysis for the preparation of anti 2-amino-1,3-propanediols 


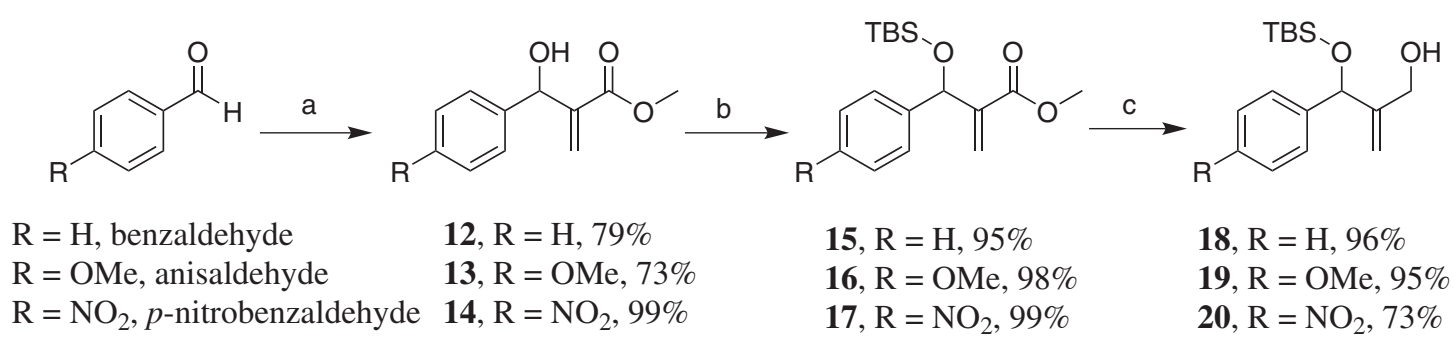

Scheme 2. Preparation of allylic diols from MBH adducts. Reagents and conditions: (a) methyl acrylate, DABCO, room temperature, ultrasound and (b) TBSCl (tert-butyldimethylsilyl chloride), imidazole, DMF or TBSOTf (tert-butyldimethylsilyl trifluoromethanesulfonate), $\mathrm{CH}_{2} \mathrm{Cl}_{2}, \mathrm{Et}_{3} \mathrm{~N}$ and (c) DIBAL- $\mathrm{H}, \mathrm{CH}_{2} \mathrm{Cl}_{2},-72{ }^{\circ} \mathrm{C}, 1 \mathrm{~h}$.

Table 1. Synthesis of 2-oxo-1,3-propanediols from MBH adducts

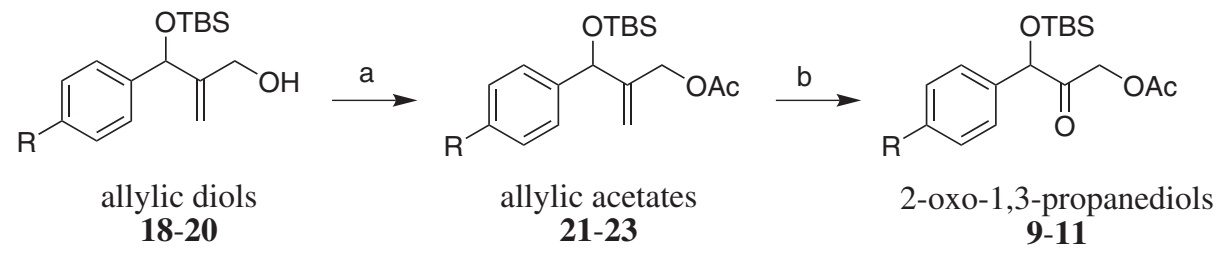

\begin{tabular}{lcccc}
\hline entry & $\mathrm{R}$ & Acetylation $/ \%^{\mathrm{a}}$ & Ozonolysis $/ \%^{\mathrm{a}}$ & ${\text { Overall yields } / \%^{\mathrm{b}}}^{\mathrm{a}}$ \\
\hline 1 & $\mathrm{H}$ & $\mathbf{2 1}, 85$ & $\mathbf{9}, 91$ & 55 \\
2 & $\mathrm{OMe}$ & $\mathbf{2 2 ,}, 90$ & $\mathbf{1 0}, 80$ & 49 \\
3 & $\mathrm{NO}_{2}$ & $\mathbf{2 3}, 90$ & $\mathbf{1 1}, 82$ & 53 \\
\hline
\end{tabular}

Reagents and conditions: (a) AcCl, $\mathrm{NEt}_{3}, \mathrm{CH}_{2} \mathrm{Cl}_{2}, 0{ }^{\circ} \mathrm{C}, 30$ min and (b) (i) $\mathrm{O}_{3}, \mathrm{MeOH},-72{ }^{\circ} \mathrm{C}, 15$ min and (ii) $\mathrm{S}\left(\mathrm{CH}_{3}\right)_{2},-72{ }^{\circ} \mathrm{C}$ to room temperature, $1 \mathrm{~h}$; ${ }^{a}$ yields refer to isolated and purified products; ${ }^{b}$ yield over 5 steps.

the products are more stable and the purification by usual chromatographic protocols becomes easier. For all these reasons, silylation increases the synthetic efficiency of this sequence since no purification steps are formally needed after ester reduction with DIBAL-H. Finally, diols 18-20 were acetylated to provide the corresponding acetates 21-23 in good yields (Table 1).

At first, one goal of this work was the selective access to oxazolidin-2-ones with different substitution patterns. To accomplish this task, it would be necessary to be able to remove selectively the protecting groups from the benzylic and primary hydroxyl groups. Thus, acetylation was used as an orthogonal protection of the primary hydroxyl. Acetates 21-23 were treated with ozone, at $-72{ }^{\circ} \mathrm{C}$, in methanol for $15 \mathrm{~min}$, followed by reductive work-up $\left[\mathrm{S}\left(\mathrm{CH}_{3}\right)_{2}\right]$ to give substituted 2-oxo-1,3-propanediols 9-11, with yields ranging from 80 up to $91 \% .{ }^{14}$ The oxo-derivatives 9-11 were therefore prepared in 5 steps from the corresponding aldehydes with good overall yields (Table 1).

Following our synthetic strategy, the oxo-compounds 9-11 were then submitted to a reductive amination step. In the literature, it is possible to find several alternatives to perform a reductive amination reaction. ${ }^{15}$

In our case, the reductive aminations were performed in methanol as a solvent, at room temperature, using $\mathrm{NH}_{4} \mathrm{OAc}$ as nitrogen source in the presence of $\mathrm{NaHCO}_{3}$. The latter was used to maintain the $\mathrm{pH}$ of the reaction under control (pH ranging from 4.5 to 6 ).

Interestingly, during the reductive amination, it was observed the migration of the acetyl group from oxygen to the newly incorporated nitrogen atom, leading to the formation of 2- $\mathrm{N}$-acetyl-1,3-propanediol. This sort of internal migration is widely known, ${ }^{16}$ mainly in the aminosugar chemistry. ${ }^{17}$

It was decided to use $\mathrm{NaBH}_{3} \mathrm{CN}$ as a source of hydride, even though it can reduce carbonyl groups at $\mathrm{pH}$ lower than $4 .{ }^{18}$ However, such side reactions were avoided since the $\mathrm{pH}$ was always maintained above 4 (ranging from 4.5 up to 6). Thus, in these conditions, oxo-compounds 9-11 afford the corresponding 2- $\mathrm{N}$-acetyl-1,3-propanediols in moderate yields, as shown in Table 2 .

Fortunately, the major component present in the crude mixture of the aminopropanediols $\mathbf{6 a} / \mathbf{b}-\mathbf{8} \mathbf{\mathbf { a }} / \mathbf{b}$ crystallizes from a mixture of ethyl acetate and hexane. Surprisingly, the analysis of the NMR (nuclear magnetic resonance) spectra of the crystallized product showed the presence of a single compound. The analysis of these spectra showed a doublet centered around $5.20 \mathrm{ppm}$ attributed to the carbinolic proton.

The products were fully characterized by the usual spectroscopic methods. The analysis of IR (infrared) spectra of the compounds $\mathbf{6 a - 8} \mathbf{-} \mathbf{a}$ showed a strong absorption near 
Table 2. Diastereoselective synthesis of substituted anti 2- $\mathrm{N}$-acetyl-1,3-propanediols<smiles>[R]c1ccc(C(O[Ga+])C(=O)COC(N)=O)cc1</smiles>

2-oxo-1,3-propanediols 9-11

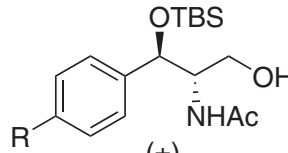

$( \pm)$

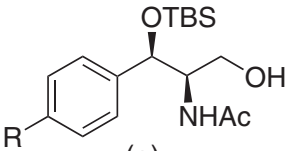

$( \pm)$

anti 2- $N$-acetyl-1,3-propanediol syn 2- $N$-acetyl-1,3-propanediol $6 \mathbf{a}-8 \mathbf{a}$ 6b-8b

\begin{tabular}{lccc}
\hline entry & $\mathrm{R}$ & Aminodiols / \% & Diastereoselectivity $\left(\right.$ anti:syn) $^{\mathrm{b}}$ \\
\hline 1 & $\mathbf{9}, \mathrm{H}$ & $\mathbf{6 a}, 52 ; \mathbf{6 b}, 8$ & $87: 13$ \\
2 & $\mathbf{1 0}, \mathrm{OMe}$ & $\mathbf{7 a}, 53 ; \mathbf{7 b}, 14$ & $79: 21$ \\
3 & $\mathbf{1 1}, \mathrm{NO}_{2}$ & $\mathbf{8 a}, 40 ; \mathbf{8 b}, 15$ & $72: 28$ \\
\hline
\end{tabular}

Reagents and conditions: (a) $\mathrm{NH}_{4} \mathrm{OAc}, \mathrm{NaBH}_{3} \mathrm{CN}, \mathrm{NaHCO}_{3}, \mathrm{MeOH}$, room temperature, $12 \mathrm{~h}$; ayields refer to isolated and purified compounds; ${ }^{b}$ diastereoselectivities were determined in the crude mixture by measuring the relative proportion between the signals at 5.2-4.95 ppm, attributed to the carbinolic protons.

to $1650 \mathrm{~cm}^{-1}$, which was assigned to the amide carbonyl group. Furthermore, the analysis of the ${ }^{1} \mathrm{H}$ NMR spectra for all nitrogenated compounds showed a characteristic doublet at $6.50 \mathrm{ppm}$ attributed to the secondary amide hydrogen and a second doublet (ranging from 5.14 to $5.29 \mathrm{ppm}$ ) attributed to the carbinolic proton. The analysis of the ${ }^{13} \mathrm{C}$ NMR spectra of these compounds shows signals around 75,61 and $55 \mathrm{ppm}$, which were attributed to the secondary and primary carbinolic carbons and to the carbon bonded to the nitrogen, respectively.

Seeking to demonstrate the synthetic versatility of our aminodiols, they were transformed into the corresponding substituted oxazolidin-2-ones. Besides the biological relevance of these cyclic intermediates, they could be subjected to nOe (nuclear Overhauser effect) experiments to confirm the relative stereochemistry. They could be compared with some oxazolidin-2-ones whose relative stereochemistries are already well established. Initially, the interest was in having the 4,5-disubstituted oxazolidin2-ones. Then, the anti-2- $N$-acetyl-1,3-propanediols 6a-7a were treated with TBAF (tetrabutylammonium fluoride) in THF (tetrahydrofuran) (at room temperature for $1 \mathrm{~h}$ ) in order to remove the silyl protecting group. The corresponding unprotected 2- $N$-acetyl-1,3-propanediols were obtained in almost quantitative yield, but were contaminated with a tiny amount of TBAF residue. Attempts to purify the compound 25a by silica gel column chromatography significantly reduced the yield. The compounds 24a and 25a were therefore used in the next step without purification.

The literature reports several methods for preparing oxazolidin-2-one from aminodiols. ${ }^{19}$ In our case, the 2- $N$-acetyl-1,3-propanediols 24a and 25a were refluxed separately in toluene in the presence of diethylcarbonate and $\mathrm{K}_{2} \mathrm{CO}_{3}$ for $1 \mathrm{~h}$. After that, the crude mixture was evaporated and redissolved in a methanol:water (1:1) mixture, which was refluxed in the presence of $\mathrm{LiOH}$ to complete the cyclization process. Under such conditions, it was recovered a mixture of 4- and 4-5-substituted oxazolidin-2-ones in moderate yields. The results are summarized in Table 3.

Table 3. Synthesis of oxazolidin-2-ones from aminodiols<smiles>[R]OC(CCO)C(N)C(=O)O</smiles><smiles>[2H]C(O)C(N)CO</smiles><smiles>C1=CCCC1</smiles>

6a, $\mathrm{R}=\mathrm{Ph}$

7a, $\mathrm{R}=4-\mathrm{MeOPh}$

anti- $N$-acetylaminodiols<smiles>O=C1NC(C(O)O)CO1</smiles>

26, $\mathrm{R}=\mathrm{Ph}$

27, $\mathrm{R}=4-\mathrm{MeO}-\mathrm{Ph}$

( \pm -anti-4-substituted oxazolidin-2-one

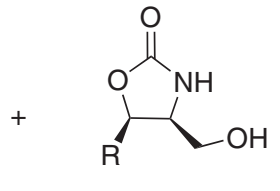

28, $\mathrm{R}=\mathrm{Ph}$

29, $\mathrm{R}=4-\mathrm{MeO}-\mathrm{Ph}$

( \pm -cis-4,5-disubstituted oxazolidin-2-one

\begin{tabular}{lccc}
\hline entry & Aminodiols & Oxazolidin-2-ones / \% & Regioisomeric ratio (4-/4,5-) \\
\hline 1 & $\mathbf{6 a}$ & $\mathbf{2 6}, 33 ; \mathbf{2 8}, 17$ & $2: 1^{\mathrm{b}}$ \\
2 & $\mathbf{7 a}$ & $\mathbf{2 7}, 51$ & $>10: 1$ \\
\hline
\end{tabular}

Reagents and conditions: (a) TBAF, $\mathrm{MeOH}$, room temperature, $1 \mathrm{~h}$ and (b) (i) $\mathrm{CO}(\mathrm{OEt})_{2}$, toluene, reflux, $\mathrm{K}_{2} \mathrm{CO}_{3}$ and (ii) $\mathrm{LiOH}, \mathrm{MeOH}: \mathrm{H}_{2} \mathrm{O}(1: 1), 1 \mathrm{~h}$;

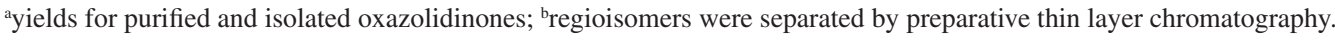


In both cases, the formation of 4-substituted oxazolidin2 -ones (26 and 27) was favorable, however, when $\mathrm{R}=\mathrm{Ph}(\mathbf{2 4 a})$, a considerable amount of regioisomeric 4,5-substituted oxazolidin-2-one was formed (28). Most likely a steric effect associated with the 4,5-substituted cis oxazolidin-2-ones leads to the formation of the more stable 4-substituted anti oxazolidinones.

The purified minor syn 2-amino-1,3-propanediol (25b) was also treated with the same cyclization conditions to provide trans-isocytoxazone (30), contaminated with traces of the regioisomeric 4-substituted oxazolidin-2-one $(>5 \%)$. Similar results were previously reported by Rozwadowska et al. ${ }^{12}$ (Scheme 3).

Our spectral data were compared to those available in the literature for ( \pm )-trans-isocytoxazone (30) and confirm that our synthesis was successfully accomplished. ${ }^{12}$ In order to collect more evidence about this compound, it was also performed some nOe studies. Thus, when the benzylic hydrogen at $5.20 \mathrm{ppm}$ was irradiated, it was observed an increment of only $0.7 \%$, compatible with a 1,2-trans relationship. ${ }^{20}$ The same protocol was used for the other 4-substituted oxazolidin-2-one (26) and $\mathbf{2 7}$. The irradiation of benzylic hydrogen at $4.6 / 4.7 \mathrm{ppm}$ showed increments of 1.4 and $1.5 \%$, respectively. These results suggest, in both cases, an anti relationship between the groups $^{21}$ (Figure 2).

The anti diastereoisomers could be rationalized from the model of 1,2-induction proposed by Cram and Felkin $^{22}$ for the reduction of ketones and imines. In this model, not only steric hindrance is considered, but also important electronic effects that can influence the transition state energy. The observed selectivity can be inferred through the formation of a chelate species envolving to the formation of a hydrogen bond between one of the hydrogens of the iminium ion and the oxygen atom of the silyl ether. Molecular orbital studies of different types of silyl ethers showed that oxygen can present chelating properties ${ }^{23}$ supporting the transition state proposed for this imine reduction. The anti diastereoisomers can be called anti-Felkin or Cram-chelate product (Figure 3).<smiles>COc1ccc(C2OC(=O)N[C@H]2CO)cc1</smiles>

syn-aminodiol (7b)

unprotected aminodiol (25b)

(士)-trans-isocytoxazone (30)

Scheme 3. Synthesis of ( \pm )-trans-isocytoxazone. Reagents and conditions: (a) TBAF, THF, $1 \mathrm{~h}$, room temperature and (b) (i) $\mathrm{CO}(\mathrm{OEt})_{2}, \mathrm{~K}_{2} \mathrm{CO}{ }_{3}$, toluene, reflux, $1 \mathrm{~h}$ and (ii) $\mathrm{LiOH}, \mathrm{MeOH}, \mathrm{H}_{2} \mathrm{O}, 1 \mathrm{~h}$, room temperature, $45 \%$ (regioisomeric ratio $>10: 1$ ).

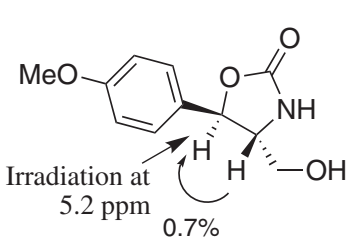

30, ( \pm -trans-isocytoxazone

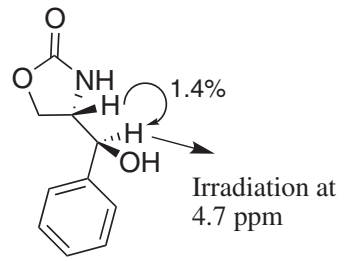

26

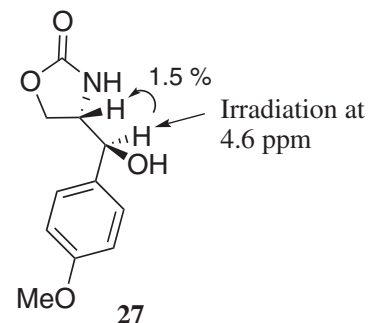

27

Figure 2. nOe differencial studies with the synthesized oxazolidin-2-ones.

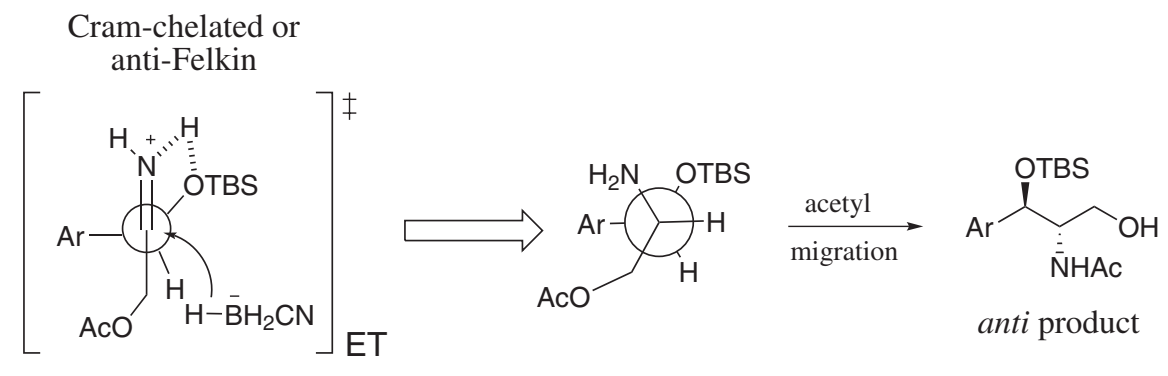

1,2-induction

Figure 3. Models of 1,2-induction through Cram-chelate or anti-Felkin processes to explain the reduction of the imine group. 


\section{Conclusions}

In summary, it is described in this work an alternative for the diastereoselective synthesis of anti 2- $\mathrm{N}$-acetyl1,3-propanediols from $\mathrm{MBH}$ adducts in 5 steps, with overall yields ranging from 25 to $42 \%$. Furthermore, from the anti-aminoalcohols $6 \mathbf{6}$ and 7a regioisomeric 4-substituted oxazolidin-2-ones $\mathbf{2 6}$ and $\mathbf{2 7}$ were obtained as the major products in 2 steps, in moderate overall yields. It is also described an alternative approach to the total synthesis of ( \pm -trans-isocytoxazone, a synthetic oxazolidino-2-one presenting anti-asthmatic properties. This compound was synthetized from the minor syn-aminoalcohol $\mathbf{7 b}$ with yield of $45 \%$ over to 2 steps. This is the first report describing the total synthesis of it from Morita-Baylis-Hillman adducts.

\section{Experimental}

The ${ }^{1} \mathrm{H}$ and ${ }^{13} \mathrm{C}$ NMR spectra were recorded on a Varian Gemini BB-300 at 300 and $75.5 \mathrm{MHz}$, Bruker 250 at 250 and $62.5 \mathrm{MHz}$ and on an Inova instrument at 500 and $125 \mathrm{MHz}$, respectively. The mass spectra (MS) were recorded using a Micromass (Manchester-UK) ESI-QqTOF (electrospray ionization quadrupole time-of-flight) with high resolution on the TOF mass analyzer and using a Premier-Waters GC/MS GCT EI-TOF, also with high resolution. Infrared (IR) spectra were obtained with a Nicolet model Impact 410. Melting points (m.p.) were measured in open capillary tubes using an Electrothermal model 9100 apparatus and were not calibrated. Manipulations and reactions were not performed under dry atmospheres or employing dry solvents, unless otherwise specified. Purification and separations by column chromatography were performed on silica gel, using normal or flash chromatography. TLC (thin layer chromatography) visualization was achieved by spraying with 5\% ethanolic phosphomolybdic acid and heating. All Morita-Baylis-Hillman reactions were sonicated in an ultrasonic cleaner UNIQUE model GA $1000(1000 \mathrm{~W}$, $25 \mathrm{kHz}$ ). Reagents were purchased from Aldrich, Acros, Synth or Merck and were used without purification.

\section{General procedure for the preparation allylic diols (18-20)}

To a stirred solution of the silylated $\mathrm{MBH}$ adduct 15-17 (5 mmol) in $20 \mathrm{~mL}$ of anhydrous dichloromethane at $-72{ }^{\circ} \mathrm{C}$, it was added quickly (under an inert gas atmosphere) a solution of DIBAL-H in toluene $\left(1.5 \mathrm{~mol} \mathrm{~L}^{-1}, 10.4 \mathrm{~mL}\right.$, $12.5 \mathrm{mmol})$. Soon after, there was the vigorous release of small bubbles, followed by a change of color of the reaction medium. After $1 \mathrm{~h}$, the analysis by TLC revealed the complete consumption of the starting material. Then, a saturated solution of sodium acetate $(7 \mathrm{~mL})$ was carefully added to the reaction flask. The resulting mixture was transferred to an erlenmeyer ( $200 \mathrm{~mL}$ ) containing $80 \mathrm{~mL}$ of ethyl ether. To the stirred mixture, it was added a saturated solution of $\mathrm{NH}_{4} \mathrm{Cl}(12 \mathrm{~mL})$ and the mixture was then stirred for $1 \mathrm{~h}$ until the observation of the precipitation of a white gel. After that, the heterogeneous mixture was filtered in a pad of celite $(0.5 \mathrm{~cm})$ under vacuum, and the precipitate was washed with ethyl ether $(3 \times 10 \mathrm{~mL})$. The organic layers were combined and washed with $15 \mathrm{~mL}$ of distilled water and $15 \mathrm{~mL}$ of brine, dried over $\mathrm{MgSO}_{4}$ and filtered. The organic solvent was removed under reduced pressure. The crude residue was used in the next step without any purification.

General procedure for the preparation of acetylated compounds (21-23)

To a stirred solution of allyl alcohol 18-20 (2 mmol) in $15 \mathrm{~mL}$ of anhydrous dichloromethane at $0{ }^{\circ} \mathrm{C}$ (under an inert gas atmosphere), it was added $\mathrm{NEt}_{3}(4 \mathrm{mmol})$ and freshly distilled acetyl chloride $(3 \mathrm{mmol})$. The reaction was followed by TLC and after 30 min no starting material was detected. Then, a saturated solution of $\mathrm{NaHCO}_{3}(10 \mathrm{~mL})$ was added to the reaction mixture. The organic layer was separated and washed with brine $(2 \times 10 \mathrm{~mL})$, dried over $\mathrm{Na}_{2} \mathrm{SO}_{4}$, filtered and concentrated under reduced pressure. The crude residue was purified by silica gel column chromatography, using a mixture of ethyl acetate:hexane (20:80), as eluent, to give the corresponding acetates as viscous oils.

General procedure for the preparation of oxo-derivatives (9-11)

Into a stirred solution of the acetylated compounds 21-23 $(1 \mathrm{mmol})$ in $10 \mathrm{~mL}$ of methanol $\left(\mathrm{at}-72^{\circ} \mathrm{C}\right)$, it was passed a slow flow of ozone. The reaction was followed by TLC until no starting material was detected. After $15 \mathrm{~min}$, dimethyl sulfide was added $\left.\left[\mathrm{S}_{(} \mathrm{CH}_{3}\right)_{2}, 10 \mathrm{mmol}\right]$ and the mixture was stirred at $-72{ }^{\circ} \mathrm{C}$ for $1 \mathrm{~h}$. Soon after, the solvents were removed under reduced pressure and the residue was diluted in ethyl acetate $(30 \mathrm{~mL})$. The organic layer was washed with brine $(2 \times 20 \mathrm{~mL})$, dried over $\mathrm{Na}_{2} \mathrm{SO}_{4}$, filtered and concentrated under reduced pressure. The crude mixture was purified by silica gel chromatography using a mixture of ethyl acetate:hexane (5:95) to provide the corresponding oxo-compounds as fluid oils.

General procedure for the preparation of aminodiols (6-8)

To a stirred solution of substituted 2-oxo-1,3-propanediols 9-11 (1 mmol) in $15 \mathrm{~mL}$ of anhydrous methanol (under an 
inert gas atmosphere), it was added $\mathrm{NaHCO}_{3}(2 \mathrm{mmol})$ and $\mathrm{NH}_{4} \mathrm{OAc}$ (30 equiv.). To the resulting mixture, it was added $\mathrm{NaBH}_{3} \mathrm{CN}$ ( 1.5 equiv.) in two portions ( 0.75 equiv. each) in intervals of $30 \mathrm{~min}$. The reaction was maintained under stirring for $12 \mathrm{~h}$. After that, the solvent was removed under reduced pressure and the crude residue was suspended in ethyl acetate $(20 \mathrm{~mL})$. The organic phase was washed with distilled water $(2 \times 10 \mathrm{~mL})$, brine $(10 \mathrm{~mL})$, dried over $\mathrm{Na}_{2} \mathrm{SO}_{4}$, filtered and concentrated under reduced pressure to furnish an amorphous solid. This solid was crystallized as following: the crude residue was dissolved in ethyl acetate (the minimum amount necessary to dissolve the product) at $50{ }^{\circ} \mathrm{C}$. Then, the resulting hot solution was transferred to a $100 \mathrm{~mL}$ erlenmeyer and hexane was added drop by drop until the solution becomes cloudy. The solution was kept in the refrigerator at $8{ }^{\circ} \mathrm{C}$ for 1 day. Then, the precipitate was filtered, washed with $20 \mathrm{~mL}$ of cold hexane to provide the anti diastereoisomer, as an amorphous solid (0.168 $\mathrm{g})$ and the syn diastereoisomer as a viscous oil (0.028 g).

General procedure for the deprotection of the TBS group

To a stirred solution of the anti 2 - $N$-acetyl1,3-propanediols $6 \mathbf{a}-7 \mathbf{a}(0.5 \mathrm{mmol})$ in $10 \mathrm{~mL}$ of anhydrous THF at $0{ }^{\circ} \mathrm{C}$ (under an inert gas atmosphere), it was added drop by drop a solution of TBAF $\left(1.0 \mathrm{~mol} \mathrm{~L}^{-1}\right.$ in THF, $1.25 \mathrm{~mL}, 1.25 \mathrm{mmol}$ ). The reaction was followed by TLC and after $1 \mathrm{~h}$ no starting material was observed. Then, the solvent was evaporated under reduced pressure and the crude residue was dissolved in ethyl acetate $(15 \mathrm{~mL})$. The organic layer was washed with a saturated solution of $\mathrm{NH}_{4} \mathrm{Cl}(1 \times 5 \mathrm{~mL})$ and brine $(1 \times 5 \mathrm{~mL})$. The aqueous layer was successively stirred with ethyl acetate in order to recover any product dissolved in water. The organic phases were combined, dried over $\mathrm{MgSO}_{4}$, filtered and concentrated under reduced pressure. The crude mixture was used without purification for the next step.

General procedure for the preparation of oxazolidin-2-one (26-27)

A solution of 2- $N$-acetyl-1,3-propanediols 24a or 25a $(0.2 \mathrm{mmol})$ in a mixture of toluene and diethylcarbonate $(1: 1,2 \mathrm{ml})$ was refluxed for $1 \mathrm{~h}$. After that, the solvent was evaporated under reduced pressure. To a stirred solution of this residue dissolved in a mixture of methanol and water (1:1, $3 \mathrm{~mL})$, it was added $\mathrm{LiOH}$ (2 mmol). After $30 \mathrm{~min}$, no starting material was detected by TLC analysis. Then, the solvent was evaporated under reduced pressure, and the residue dissolved in ethyl acetate $(15 \mathrm{~mL})$. The organic phase was washed with distilled water $(3 \times 10 \mathrm{~mL})$, dried over $\mathrm{Na}_{2} \mathrm{SO}_{4}$, filtered and concentrated under reduced pressure. When $\mathrm{R}=4-\mathrm{MeO}-\mathrm{Ph}-$, no purification was needed because only one product was observed. However, when $\mathrm{R}=\mathrm{Ph}-$, a preparative plate was performed to separate the regioisomers. The eluent was a mixture (v:v:v) of hexane:methanol:dichloromethane (1:4.5:4.5).

\section{Supplementary Information}

Spectra of compounds synthesized in this manuscript are available free of charge at http://jbcs.sbq.org.br.

\section{Acknowledgments}

P. H. S. P. thanks Fundação de Amparo à Pesquisa do Estado de São Paulo (Fapesp) for your grant. F. C. thanks Fapesp and Conselho Nacional de Desenvolvimento Científico e Tecnológico (CNPq) for financial support and research grant. We thank Professor Carol Collins for the English revision of this manuscript

\section{References}

1. Rebstock, M. C.; Crooks Jr., H. M.; Controulis, J.; Bartz, Q. R.; J. Am. Chem. Soc. 1949, 71, 2458; Controulis, J.; Rebstock, M. C.; Crooks Jr., H. M.; J. Am. Chem. Soc. 1949, 71, 2463; Long, L. M.; Troutman, H. D.; J. Am. Chem. Soc. 1949, 71, 2469; Long, L. M.; Troutman, H. D.; J. Am. Chem. Soc. 1949, 71, 2473; Hajra, S.; Karmakar, A.; Maji, T.; Medda, A. M.; Tetrahedron 2006, 62, 8959; Veeresa, G.; Datta, A.; Tetrahedron Lett. 1998, 39, 8503; Boruwa, J.; Borah, J. C.; Gogoi, S.; Barua, N. C.; Tetrahedron Lett. 2005, 46, 1743.

2. Wu, G.; Schumacher, D. P.; Tormos, W.; Clark, J. E.; Murphy, B. L.; J. Org. Chem. 1997, 62, 2996; Towson, J. C.; PTC Int. Appl. WO Patent 2007/030405-A2 2007 (CA 146:295904); Wu, G.-Z.; Tormos, W. I.; PTC Int. Appl. WO Patent 1994/14764 1994 (CA 121:133722).

3. Hughes, A. B.; Rudge, A. J.: Nat. Prod. Rep. 1994, 11, 135; Liang, P.; Cheng, W.; Lee, Y.; Yu, H.; Wu, Y.; Lin, Y.; Wong, C.; Chem. Bio. Chem. 2006, 7, 165.

4. Ahmed, S. A.; Khalifa, S. I.; Hamann, M. T.; J. Nat. Prod. 2008, $71,513$.

5. Danielmeier, K.; Steckhan, E.; Tetrahedron: Asymmetry 1995, 6, 1181; Burghardt, H.; Schimz, K.; Müller, M.; FEBS Lett. 1998, 425, 40; Eustice, D. C.; Feldman, P. A.; Slee, A. M.; Biochem. Biophys. Res. Commun. 1988, 150, 965; Hancock, R. E. W.; Lancet Infect. Dis. 2005, 5, 209; Silveira, G. P.; Nome, F.; Gesser, J. C.; Sá, M. M.; Quim. Nova 2006, 29, 844; Walsh, D. A.; Yanni, J. M.; U.S. pat. 5,086,055 1992 (CA 116:188072r); Gregory, W. A.; Britelli, D. R.; Wang, C. L. J.; Wuonola, M. A.; 
McRipley, R. J.; Eustine, D. C.; Eberly, V. S.; Bartholomew, P. T.; Slee, A. M.; Forbes, M.; J. Med. Chem. 1989, 32, 1673; Eustice, D. C.; Brittelli, D. R.; Feldman, P. A.; Brown, L. J.; Borkowshi, J. J.; Slee, A. M.; Drugs Exp. Clin. Res. 1990, 16, 149; Brickner, S. J.; Curr. Pharm. Design 1996, 2, 175; for some examples of oxazolidin-2-one as chiral auxiliary, see: Evans, D. A.; Ng, H. P.; Rieger, D. L.; J. Am. Chem. Soc. 1993, 115, 11446; Evans, D. A.; Ng, H. P.; Rieger, D. L.; J. Am. Chem. Soc. 1993, 115, 11446; Gaul, C.; Scharer, K.; Seebach, D.; J. Org. Chem. 2001, 66, 3059; Yamamoto, H.; Watanabe, S.; Kadotani, K.; Hasegawa, M.; Noguchi, M.; Kanemasa, S.; Tetrahedron Lett. 2000, 41, 3131; Faita, G.; Paio, A.; Quatrelli, P.; Rancati, F.; Seneci, P.; Tetrahedron Lett. 2000, 41, 1265; Rosenstein, I. J.; Tynan, T. A.; Tetrahedron Lett. 1998, 39, 8429; Gibson, C. L.; Gillon, K.; Cook, S.; Tetrahedron Lett. 1998, 39, 6733; Nakamura, T.; Hashimoto, N.; Ishizuka, T.; Kunieda, T.; Tetrahedron Lett. 1997, 38, 559.

6. Hayes, K.; Gever, G.; J. Org. Chem. 1951, 16, 269; Matsumoto, T.; Hata, K.; J. Am. Chem. Soc. 1957, 79, 5506; Smith, M. E. B.; Chen, B. H.; Hibbert, E. G.; Kaulmann, U.; Smithies, K.; Galman, J. L.; Baganz, F.; Dalby, P. A.; Hailes, H. C.; Lye, G. J.; Ward, J. M.; Woodley , J. M.; Micheletti, M.; Org. Process Res. Dev. 2010, 14, 99; Smithies, K; Smith, M. E. B; Kaulmann, U.; Galman, J. L.; Ward, J. M.; Hailes, H. C.; Tetrahedron: Asymmetry 2009, 20, 570; Restorp, P.; Somfai, P.; Org. Lett. 2005, 7, 893; Suami, T.; Umezawa, S.; Bull. Chem. Soc. Jpn. 1956, 29, 979; Nakamura, T.; Shiozaki, M.; Tetrahedron 2001 , 57, 9087; Nakamura, T.; Shiozaki, M.; Tetrahedron. Lett. 2001, 42, 2701; Hannun, Y. A.; Obeid, L. M.; J. Biol. Chem. 2002 , 277, 25847; Effenberg, F.; Guterer, B.; Syed, J.; Tetrahedron: Asymmetry 1995, 6, 2933.

7. Amarante, G. W.; Coelho, F.; Tetrahedron 2010, 66, 6749; Amarante, G. W.; Benassi, M.; Pascoal, R. N.; Eberlin, M. N.; Coelho, F.; Tetrahedron 2010, 66, 4370; Amarante, G. W.; Rezende, P.; Cavallaro, M.; Coelho, F.; Tetrahedron Lett. 2008, 49, 3744; Amarante, G. W.; Cavallaro, M.; Coelho, F.; Tetrahedron Lett. 2010, 51, 2597; Amarante, G. W.; Benassi, M.; Milagre, H. M. S.; Braga, A. A. C.; Maseras, F.; Eberlin, M. N.; Coelho, F.; Chem. Eur. J. 2009, 15, 12460; Kohn, L. K.; Pavam, C. H.; Veronese, D.; Coelho, F.; de Carvalho, J. E.; Almeida, W. P.; Eur. J. Med. Chem. 2006, 41, 738.

8. Shi, M.; Wang, F.-J.; Zhao, M.-X.; Wei, Y. In The Chemistry of the Morita-Baylis-Hillman Reaction; RSC Publishing: Cambrigde, UK, 2011; Basavaiah, D.; Reddy, B. S.; Badsara, S. S.; Chem.Rev. 2010, 110,5447; Souza, R. O. M.A.; Miranda,L.S.M.; Mini-Rev. Org. Chem. 2010, 7, 212; Singh, V.; Batra, S.; Tetrahedron 2008, 64, 4511; Basavaiah, D.; Rao, K. V.; Reddy, R. J.; Chem. Soc. Rev. 2007, 36, 1581; Almeida, W. P.; Coelho, F.; Quim. Nova 2001, 23

9. Mateus, C. R.; Coelho, F.; J. Braz. Chem. Soc. 2005, 16, 386; Lopes, E. C. S.; Coelho, F.; J. Braz. Chem. Soc. 2007, 18, 1415.
10. Tamai, K.; Kichikai, K.; Nishikawa, M.; Mori, K.; Japanese Patent Office JP2004331523-A 2004 (CA 142:1014198).

11. Amarante, G. W.; Cavallaro, M.; Coelho, F.; J. Braz. Chem. Soc. 2011, 22, 1568

12. Rozwadowska, M. D.; Tomczak, A.; Tetrahedron: Asymmetry 2009, 20, 2048; Shimamoto, K.; Ohfune, Y.; Tetrahedron Lett. 1988, 29, 5177; Page, P. C. B.; Buckley, B. R.; Farah, M. M.; Blacker, A. J; Eur. J. Org. Chem. 2009, 3413; Page, P. C. B.; Buckley, B. R.; Rassias, G. A.; Blacker, A. J.; Eur. J. Org. Chem. 2006, 803; Grajewska, A.; Rozwadowska, M. D.; Tetrahedron: Asymmetry 2007, 18, 803; Kwit, M.; Rozwadowska, M. D.; Gawronski, J.; Grajewska, A.; J. Org Chem. 2009, 74, 8051; Swamy, N. R.; Krishnaiah, P.; Reddy, N. S.; Venkateswarlu, Y.; J. Carbohydr. Chem. 2004, 23, 217; Grajewska,A.; Rozwadowska, M. D.; Gzella, A.; Pol. J. Chem. 2007, 81, 1861; Giorgio, E.; Roje, M.; Tanaka, K.; Hamersak, Z.; Sunjic, V.; Nakanishi, K.; Rosini, C.; Berova, N.; J. Org. Chem. 2005, 70, 6557; Hamersak, Z.; Sepac, D.; Ziher, D.; Sunjic, V.; Synthesis 2003, 375.

13. Coelho, F.; Almeida, W. P.; Veronese, D.; Mateus, C. R.; Lopes, E. C. S.; Rossi, R. C.; Silveira, G. P. C.; Pavam, C. H.; Tetrahedron 2002, 58, 7437.

14. Abella, C. A. M.; Rezende, P.; Souza, M. F. L.; Coelho, F.; Tetrahedron Lett. 2008, 49, 145; Frezza, M.; Soulère, L.; Queneau, Y.; Doutheau, A.; Tetrahedron Lett. 2005, 46, 6495.

15. Baxter, E. W.; Reitz, A. B.; Org. React. 2002, 1, 59; Tarasevich, V. A.; Kozloz, N. G.; Russ. Chem. Rev. 1999, 68, 55; Dangerfield, E. M.; Plunkett, C. H.; Win-Mason, A. L.; Stocker, B. L.; Timmer, M. S. M.; J. Org. Chem. 2010, 75, 5470; Li, C.; Villa-Marcos, B.; Xiao, J.; J. Am. Chem. Soc. 2009, 131, 6967; Lee, O. Y.; Law, K.-L.; Ho, C.-Y; Yang, D.; J. Org. Chem. 2008, 73, 8829; Alonso, F.; Riente, P.; Yus, M.; Synlett 2008, 1289; Lehmann, F.; Scobie, M.; Synthesis 2008, 1679; Li, C.; Liang, Y.; Antilla, J. C.; J. Am. Chem. Soc. 2007, 129, 5850; Menche, D.; Arikan, F.; Li, J.; Rudolph, S.; Org. Lett. 2007, 9, 267; Zhou, J.; List, B.; J. Am. Chem. Soc. 2007, 129, 7498; McLaughlin, M.; Palucki, M.; Davies, I. W.; Org. Lett. 2006, 8, 3307; Cho, B. T.; Kang, S. K.; Tetrahedron 2005, 61, 5725.

16. Yamaguchi, T.; Hesek, D.; Lee, M.; Oliver, A. G.; Mobashery, S.; J. Org. Chem. 2010, 75, 3515; Kamerling, J. P.; Schauer, R.; Shukla, A. K.; Stoll, S.; Van Halbeek, H.; Vliegenthart, J. F. G.; Eur. J. Biochem. 1987, 162, 601; Sakurai, H.; Ishimaru, T.; Bull. Chem. Soc. Jpn. 1969, 42, 3524; Horton, D.; Mast, W. E.; Philips, K. D.; J. Org. Chem. 1967, 32, 1471.

17. Gorbach, V.; Krasikova, I.; Luk'yanov, P.; Solov'eva, T.; Ovodov, Y.; Izv. Akad. Nauk SSSR, Ser. Khim. 1987, 2106 (CA 109:55091); Patel, A.; Poller, R.; Rec. Trav. Chim. Pays-Bas. 1988, 107, 182 (CA 109:211336); Yamasaki, T.; Kubota, Y.; Tsuchiya, T.; Umezawa, S.; Bull. Chem. Soc. Jpn. 1976, 49, 3190.

18. Abdel-Magid, A. F.; Carson, K. G.; Harris, B. D.; Maryanoff, C. A.; Shah, R. D.; J. Org. Chem. 1996, 61, 3849; Borch, R.; 
Bernstein, M.; Durst, H.; J. Am. Chem. Soc. 1971, 93, 2897; Borch, R. F.; Durst, H. D.; J. Am. Chem. Soc. 1969, 91, 3996.

19. Hamdach, A.; Bentama, A.; Gil, S.; Zaballos-Garcia, E.; Sepulveda-Arques, J.; Zaragoza, R. J.; Lett. Org. Chem. 2006, 3, 477; Langlois, N.; Moro, A.; Eur. J. Org. Chem. 1999, 3483.

20. Futagawa, S.; Inui, T.; Shiba, T.; Bull. Chem. Soc. Jpn. 1973, 46, 3308; Parrodi, C. A.; Clara-Sosa, A.; Perez, L.; Quintero, L.; Maranon, V.; Toscano, R. A.; Avina, J. A.; Rojas-Lima, S.; Juaristi, E.; Tetrahedron: Asymmetry 2001, 12, 69; Spasov, S. L.; Stefanovskii, Y. N.; Kurtev, B. I.; Fodor, G.; Chem. Ber. 1972, 105, 2462; Wohl, R. A.; J. Org. Chem. 1973, 38, 3858.
21. Rezende, P.; Paioti, P. H. S.; Coelho, F.; Synth. Commun. 2011, 41, 227.

22. Mengel, A.; Reiser, O.; Chem. Rev. 1999, 99, 1191.

23. Dias, L. C.; Ferreira, M. A.; Tormena, C. F.; J. Phys. Chem. A 2008, 112, 232; Stanton, G. R.; Koz, G.; Walsh, P. J.; J. Am. Chem. Soc. 2011, 133, 7969; Santon, G. R.; Johnson, C. N.; Walsh, P. J.; J. Am. Chem. Soc. 2010, 132, 4399.

Submitted: August 16, 2011 Published online: December 1, 2011

FAPESP has sponsored the publication of this article. 